\title{
Cell cycle kinetics in pterygium at three latitudes
}

Sree R K Karukonda, Hilary W Thompson, Roger W Beuerman, Dennis S C Lam, Russell Wilson, Sek Jin Chew, Thomas L Steinemann

LSU Eye Center,
Louisiana State
University Medical
Center School of
Medicine, New
Orleans, Louisiana,
USA
Sree R K Karukonda
Hilary W Thompson
Roger W Beuerman
Sek Jin Chew
Department of
Ophthalmology and
Visual Sciences, The
Chinese University of
Hong Kong
Dennis S C Lam
Department of
Pathology, Tulane
University College of
Medicine, New
Orleans, Louisiana,
USA
Russell Wilson
Department of
Ophthalmology,
University of Arkansas
for Medical Sciences,
Little Rock, Arkansas,
USA
Thomas L Steinemann
Correspondence to: Dr
Roger W Beuerman,
LSU Eye Center,
2020 Gravier Street, Suite B,
New Orleans, LA 70112,
USA.
Accepted for publication
20 October 1994

LSU Eye Center, Louisiana State Medicine, New Oriean

Sree R K Karukonda Hilary W Thompson Sek Jin Chew

Department of Visual Sciences, Th Chinese University of Hong Kong

Dennis S C Lam Pathology, Tulane Medicine, New

Department of Ophthalmology, University of Arkansas for Medical Sciences, USA

Correspondence to: $\mathrm{D}$ Roger W Beuerman, LSU Eye Center, 2020 Gravier Street, Suite B, USA. 20 October 1994

\begin{abstract}
The cell cycle kinetics of 93 specimens of pterygial tissue, as well as 19 specimens of normal conjunctiva, from patients at three sites representing three different latitudes (Singapore, $1^{\circ}$; Hong Kong, $2^{\circ}$; and Little Rock, Arkansas, $34^{\circ}$ ) were evaluated by flow cytometry. The results showed no difference in cellular proliferation patterns between pterygial and conjunctival tissue at any of the sites, suggesting that pterygium is not a disorder of excess cellular proliferation. Transmission electron microscopy showed extracellular matrix to be a prominent component of pterygium. Cellular proliferation patterns of primary and recurrent pterygium were not significantly different from each other. Factors associated with increased incidence of pterygium included male sex, outdoor occupation, and advanced age.

(Br f Ophthalmol 1995; 79: 313-317)
\end{abstract}

Pterygium is a disorder of the ocular surface with a worldwide distribution. The lesion consists of an overgrowth of bulbar conjunctiva on the cornea that is often disfiguring and may eventually obstruct the visual axis. The aetiology and pathogenesis of pterygium are not clearly understood ${ }^{1-7}$; current theories include ultraviolet light exposure ${ }^{2}$ infrared light exposure, $^{3}$ chronic inflammation, ${ }^{45}$ elastodysplasia and elastodystrophy, ${ }^{6}$ and stem cell aplasia. ${ }^{7}$ The recurrent nature of this lesion $(40-90 \%)$ is a significant problem for the patient as well as for the surgeon. ${ }^{18-10}$ Attempts to reduce the rate of recurrence have involved excision ofthe pterygium by the bare sclera method followed by a variety of adjunctive measures such as mitomycin drops, ${ }^{11} 12$ triethylene thiophosphoramide, ${ }^{13}$ $\beta$ radiation, ${ }^{14} 15$ thermal cautery, ${ }^{16}$ and conjunctival transplants. ${ }^{17}$

Cameron's global survey of pterygium established a direct relation between prevalence rates and proximity to the equator. ${ }^{2}$ For example, locations at $12^{\circ}$ of latitude have prevalence rates as high as $22.5 \%$, compared with $2 \%$ at locations above the 40 th parallel. High rates of prevalence (5-15\%) are noted in the southern part of the United States. Pterygium occurs twice as often in men as in women, ${ }^{1}$ and is more common in farmers than in city dwellers and also in people who do not wear spectacles, compared with those who do. ${ }^{118}$ While prevalence is highest in the elderly, development of new cases (incidence) is highest between the ages of 20 and $40 .{ }^{1}$ With increasing longevity of populations around the world, pterygium may be seen more often in the future.

Whether pterygium is a proliferative or a metabolic disorder has not been resolved, Although Austin et $a l^{6}$ indicated that pterygium is a disorder of extracellular matrix production, most of the recent trends in treatment $^{11}{ }^{13-15}$ have been directed towards controlling mitotic activity. We used flow cytometry to determine cell cycle kinetics in specimens from patients with primary and recurrent pterygium, in comparison with normal conjunctiva, in an attempt to clarify the nature of this lesion.

\section{Materials and methods}

SPECIMEN COLLECTION

A total of 93 tissue specimens were obtained from patients who sought treatment for pterygium at three locations representing three different northern latitudes: National University Hospital, Singapore, $1^{\circ}$ (1991-2); Prince of Wales Hospital, Hong Kong, $22^{\circ}$ (1992-3); and Department of Ophthalmology, University of Arkansas School of Medicine, Little Rock, Arkansas, USA, 34 ${ }^{\circ}$ (1992-3). Nineteen samples of normal limbal conjunctiva surgically excised from patients without pterygium were also obtained from each of the three centres for comparison. Normal conjunctiva was obtained from areas not adjacent to the pterygium or from contralateral eyes, with permission from the patient.

In all cases, the bare sclera method was used to excise the pterygium. During excision, the samples were debrided of conjunctiva. Excised pterygium and normal conjunctiva were shipped to New Orleans in 50:50 ethanol:saline by courier service within 3 days of removal.

Patient data concerning primary versus recurrent lesions were available for specimens from Hong Kong and Little Rock. Information about the sex, occupation, and age of the pterygium patients was provided for the specimens from Hong Kong.

\section{FLOW CYTOMETRY}

Specimens of both pterygium and conjunctiva were analysed using flow cytometry (Epics Profile 1, Coulter Electronics, Inc, Hialeah, FL, USA). Cells were lysed and nuclei were collected using methods described previously. ${ }^{19}$ This technique chemically and mechanically disrupts cell membranes to provide the isolated nuclei that are used in the flow cytometry procedure, which therefore is not affected by overall cell size or cell 
Table 1 Percentage of cells in each cell cycle phase in pterygium and conjunctiva

\begin{tabular}{|c|c|c|c|c|c|c|c|}
\hline \multirow{2}{*}{$\begin{array}{l}\text { Study } \\
\text { population }\end{array}$} & \multirow{2}{*}{$\begin{array}{l}\text { Number of } \\
\text { specimens }\end{array}$} & \multicolumn{2}{|c|}{ G1 (growth) phase } & \multicolumn{2}{|c|}{$S$ (synthetic) phase } & \multicolumn{2}{|c|}{ G2M (mitotic) phase } \\
\hline & & LSME & $95 \% C L I$ & LSME & $95 \% C L I$ & $L S M E$ & $95 \% C L I$ \\
\hline $\begin{array}{l}\text { Singapore } \\
\text { Pterygium } \\
\text { Conjunctiva }\end{array}$ & $\begin{array}{r}39 \\
6\end{array}$ & $\begin{array}{l}78 \cdot 4 \% \text { a } \\
79 \cdot 5 \%\end{array}$ & $\begin{array}{l}(61 \cdot 9-94 \cdot 9) \\
(61 \cdot 9-97 \cdot 1)\end{array}$ & $\begin{array}{l}14 \cdot 2 \% \%^{\mathrm{b}} \\
12 \cdot 3 \%\end{array}$ & $\begin{array}{l}(-1 \cdot 7-30 \cdot 1) \\
(-4 \cdot 6-29 \cdot 3)\end{array}$ & $\begin{array}{l}7 \cdot 4 \% \%^{\mathrm{c}} \\
8 \cdot 1 \%{ }^{\mathrm{d}}\end{array}$ & $\begin{array}{l}(0 \cdot 8-14 \cdot 0) \\
(1 \cdot 1-15 \cdot 2)\end{array}$ \\
\hline $\begin{array}{l}\text { Hong Kong } \\
\text { Pterygium } \\
\text { Conjunctiva } \\
\text { Little Rock }\end{array}$ & $\begin{array}{l}48 \\
11\end{array}$ & $\begin{array}{l}90 \cdot 9 \% \%^{\mathrm{a}, \mathrm{e}} \\
79 \cdot 3 \%^{\mathrm{e}}\end{array}$ & $\begin{array}{l}(79 \cdot 6-102 \cdot 2) \\
(67 \cdot 6-91 \cdot 0)\end{array}$ & $\begin{array}{c}5 \cdot 8 \%^{\mathrm{b}, \mathrm{f}} \\
17 \cdot 3 \%^{\mathrm{f}}\end{array}$ & $\begin{array}{l}(-5 \cdot 1-16 \cdot 7) \\
(6 \cdot 0-28 \cdot 6)\end{array}$ & $\begin{array}{l}3 \cdot 3 \% \%^{c} \\
3 \cdot 4 \%{ }^{d}\end{array}$ & $\begin{array}{l}(1 \cdot 0-5 \cdot 6) \\
(1 \cdot 0-5 \cdot 8)\end{array}$ \\
\hline $\begin{array}{l}\text { Pterygium } \\
\text { Conjunctiva }\end{array}$ & $\begin{array}{l}6 \\
2\end{array}$ & $\begin{array}{l}94.6 \% \%^{\mathrm{a}, \mathrm{e}} \\
85.0 \% \%^{\mathrm{e}}\end{array}$ & $\begin{array}{l}(87 \cdot 1-102 \cdot 1) \\
(76 \cdot 5-93 \cdot 6)\end{array}$ & $\begin{array}{c}3 \cdot 7 \% \text { b,f } \\
13 \cdot 0 \%{ }^{\mathrm{f}}\end{array}$ & $\begin{array}{l}(-3 \cdot 6-11 \cdot 1) \\
(4 \cdot 6-21 \cdot 4)\end{array}$ & $\begin{array}{l}1 \cdot 7 \% \mathrm{c} \\
2 \cdot 0 \% \mathrm{~d}\end{array}$ & $\begin{array}{l}(-1 \cdot 2-4 \cdot 4) \\
(-1 \cdot 2-5 \cdot 2)\end{array}$ \\
\hline
\end{tabular}

LSME=least square means; $95 \% \mathrm{CLI}=95 \%$ confidence limit intervals derived from the ANOVA.

a Singapore significantly less than Hong Kong or Little Rock $(p=0.0001, F$ test, ANOVA).

$b, c, d$ Singapore significantly greater than Hong Kong or Little Rock $(p=0.0001, F$ test, ANOVA).

ePterygium significantly greater than conjunctiva $(\mathrm{p}=0.0001, F$ test, ANOVA).

Pterygium significantly less than conjunctiva $(p=0.0001, F$ test, ANOVA).

All other comparisons between pterygium and conjunctiva in a given phase and location or between a given tissue and phase across locations are not significant ( $p>0.05, F$ test, ANOVA).

characteristics. Samples were stained with propidium iodide. Optimal signal to noise ratio for collection of the propidium iodide fluorescence was obtained using a $575 \mathrm{~nm}$ band pass filter with a $20 \mathrm{~nm}$ pass band (Coulter Electronics).

The flow cytometer was set to acquire a maximum of 25000 events, which included cellular debris. Cell debris and unlysed cells were excluded from the analysis by selective gating. The $2 \mathrm{~N}$ and $4 \mathrm{~N}$ peaks were established by analysis of nuclei from human white blood cells stained under the same conditions as the specimen nuclei. The percentages of cells in the three phases of the cell cycle - G1 (growth phase), S (synthetic phase), and G2M (tetraploid mitotic phase) - were calculated using the quadratic method with cytologic software (Coulter Electronics, version 2.01).

\section{ELECTRON MICROSCOPY}

A mixed aldehyde fixative solution consisting of $2 \%$ glutaraldehyde, $1 \%$ paraformaldehyde, and $0.01 \%$ picric acid in a $0.1 \mathrm{M}$ sodium cacodylate buffer, $\mathrm{pH} 7 \cdot 4$, was supplied to each of the collection sites by Dr Beuerman (LSU Eye Center, New Orleans). Tissue specimens for transmission electron microscopy were placed in the solution at each of the hospital sites and shipped to New Orleans for processing and analysis. Thick sections were made for orientation, and thin sections were examined by transmission electron microscopy (Zeiss EM $10 \mathrm{C} / \mathrm{CR}$ ).

\section{STATISTICAL ANALYSIS}

A factorial design in the analysis of variance (ANOVA) was used to compare the percentages of cells in each phase of the cell cycle for the following factors: source of sample (pterygium or conjunctiva), primary or recurrent pterygium, and geographical site of origin (Singapore, Hong Kong, or Little Rock, Arkansas). ${ }^{20}$ In addition to the overall ANOVA significance, least square means, and individual confidence limits derived from this ANOVA were used in the comparison of the cell cycle values. ${ }^{21}$ The effects of occupation, sex, and age of patients were tabulated and relative frequencies were examined; relations between these variables were examined in a factor analysis. ${ }^{22}$ The factor extraction method used was principal component analysis; three factors were retained, accounting for $71 \%$ of the total variance of the data. No factor rotations were performed. Non-numeric variable sex was coded as male $=0$, female $=1$; race as white $=0$, mongoloid $=1$; occupation as indoor $=0$, outdoor $=1$; and status of recurrence as secondary $=0$, primary $=1$. A matrix of correlations between the variables was used as input to the factor analysis. All data manipulation and analysis were carried out using programs and procedures in the SAS language (Statistical Analysis System, SAS Institute, Inc, Cary, North Carolina, USA).

\section{Results}

\section{FLOW CYTOMETRY}

Flow cytometry provided no evidence for increased proliferation in pterygial tissue, compared with normal conjunctiva, at any of the latitudes studied. There were no significant differences between pterygium and normal conjunctival specimens in terms of the percentage of cells in the G2M (mitotic) phase at any of the three latitudes ( $p>0.05, F$ test, ANOVA; Table 1). In Hong Kong and Little Rock, pterygium specimens showed significantly more G1 (growth) phase nuclei and fewer S (synthetic) phase nuclei, compared with normal conjunctiva $(\mathrm{p}=0.0001, F$ test, ANOVA), but the percentages of nuclei in the mitotic phase were similar.

Geographically, specimens from Singapore, which is closest to the equator, showed significantly higher mitotic activity, compared with the other two sites. Samples of both pterygium and normal conjunctiva from Singapore had significantly greater percentages of G2M (mitotic) nuclei, compared with the respective samples from either Hong Kong or Little Rock $(p=0.0001, F$ test, ANOVA; Table 1$)$. The Singapore samples also showed significantly fewer growth phase nuclei and more synthetic phase nuclei, compared with the other two sites ( $\mathrm{p}=0.0001, F$ test, ANOVA).

Specimens from recurrent lesions were not more proliferative in nature than specimens 
Table 2 Percentage of cells in each cell cycle phase in primary and recurrent pterygia

\begin{tabular}{|c|c|c|c|c|c|c|c|}
\hline \multirow{2}{*}{$\begin{array}{l}\text { Study } \\
\text { population }\end{array}$} & \multirow{2}{*}{$\begin{array}{l}\text { Number of } \\
\text { specimens }\end{array}$} & \multicolumn{2}{|c|}{ G1 (growth) phase } & \multicolumn{2}{|c|}{$S$ (synthetic) phase } & \multicolumn{2}{|c|}{ G2M (mitotic) phase } \\
\hline & & LSME & $95 \% C L I$ & LSME & $95 \% C L I$ & LSME & $95 \% C L I$ \\
\hline $\begin{array}{l}\text { Hong Kong } \\
\text { Primary pterygium } \\
\text { Recurrent pterygium } \\
\text { First recurrence } \\
\text { Second recurrence } \\
\text { Third recurrence } \\
\text { Little Rock }\end{array}$ & $\begin{array}{r}30 \\
18 \\
13 \\
3 \\
2\end{array}$ & $\begin{array}{l}91 \cdot 0 \% \\
90 \cdot 6 \% \\
90 \cdot 6 \% \\
88 \cdot 1 \% \\
94 \cdot 4 \%\end{array}$ & $\begin{array}{l}(83 \cdot 1-98 \cdot 9) \\
(82 \cdot 6-98 \cdot 6) \\
(82 \cdot 7-98 \cdot 6) \\
(79 \cdot 2-96 \cdot 9) \\
(85 \cdot 0-103 \cdot 8)\end{array}$ & $\begin{array}{l}\mathbf{5} \cdot \mathbf{8} \% \\
\mathbf{5} \cdot 9 \% \\
\mathbf{5} \cdot 5 \% \\
\mathbf{9} \cdot 1 \% \\
3 \cdot 6 \%\end{array}$ & $\begin{array}{l}(-1 \cdot 0-12 \cdot 5) \\
(-1 \cdot 0-12 \cdot 7) \\
(-1 \cdot 3-12 \cdot 2) \\
(1 \cdot 6-16 \cdot 6) \\
(-4 \cdot 3-11 \cdot 6)\end{array}$ & $\begin{array}{l}3 \cdot 2 \% \\
3 \cdot 5 \% \\
3.9 \% \\
2 \cdot 8 \% \\
2 \cdot 0 \%\end{array}$ & $\begin{array}{l}(0 \cdot 9-5 \cdot 5) \\
(1 \cdot 2-5 \cdot 8) \\
(1 \cdot 7-6 \cdot 1) \\
(0 \cdot 4-5 \cdot 3) \\
(-0 \cdot 7-4 \cdot 6)\end{array}$ \\
\hline $\begin{array}{l}\text { Primary pterygium } \\
\text { Recurrent pterygium }\end{array}$ & $\begin{array}{l}4 \\
2\end{array}$ & $\begin{array}{l}93.9 \% \\
96.7 \%\end{array}$ & $\begin{array}{l}(86 \cdot 1-101 \cdot 7) \\
(88 \cdot 1-105 \cdot 2)\end{array}$ & $\begin{array}{l}4 \cdot 8 \% \\
1 \cdot 1 \%\end{array}$ & $\begin{array}{l}(-1 \cdot 3-10 \cdot 9) \\
(-5 \cdot 6-7 \cdot 8)\end{array}$ & $\begin{array}{l}1 \cdot 3 \% \\
2 \cdot 2 \%\end{array}$ & $\begin{array}{l}(-2 \cdot 9-5 \cdot 5) \\
(-2 \cdot 4-6 \cdot 9)\end{array}$ \\
\hline
\end{tabular}

Data on primary and recurrent pterygia in Singapore not available. Data on sequential recurrences in Little Rock not available. LSME=least square means; $95 \% \mathrm{CL}=95 \%$ confidence limit intervals derived from the ANOVA. None of the comparisons within a given phase is significant ( $p>0 \cdot 05, F$ test, ANOVA).

from primary lesions. The specimens from Hong Kong and Little Rock were labelled as primary or recurrent pterygium, and the specimens of recurrent disease from Hong Kong were further subdivided into first, second, or third recurrence (Table 2). No significant changes in the percentages of nuclei in the mitotic phase (or within any other

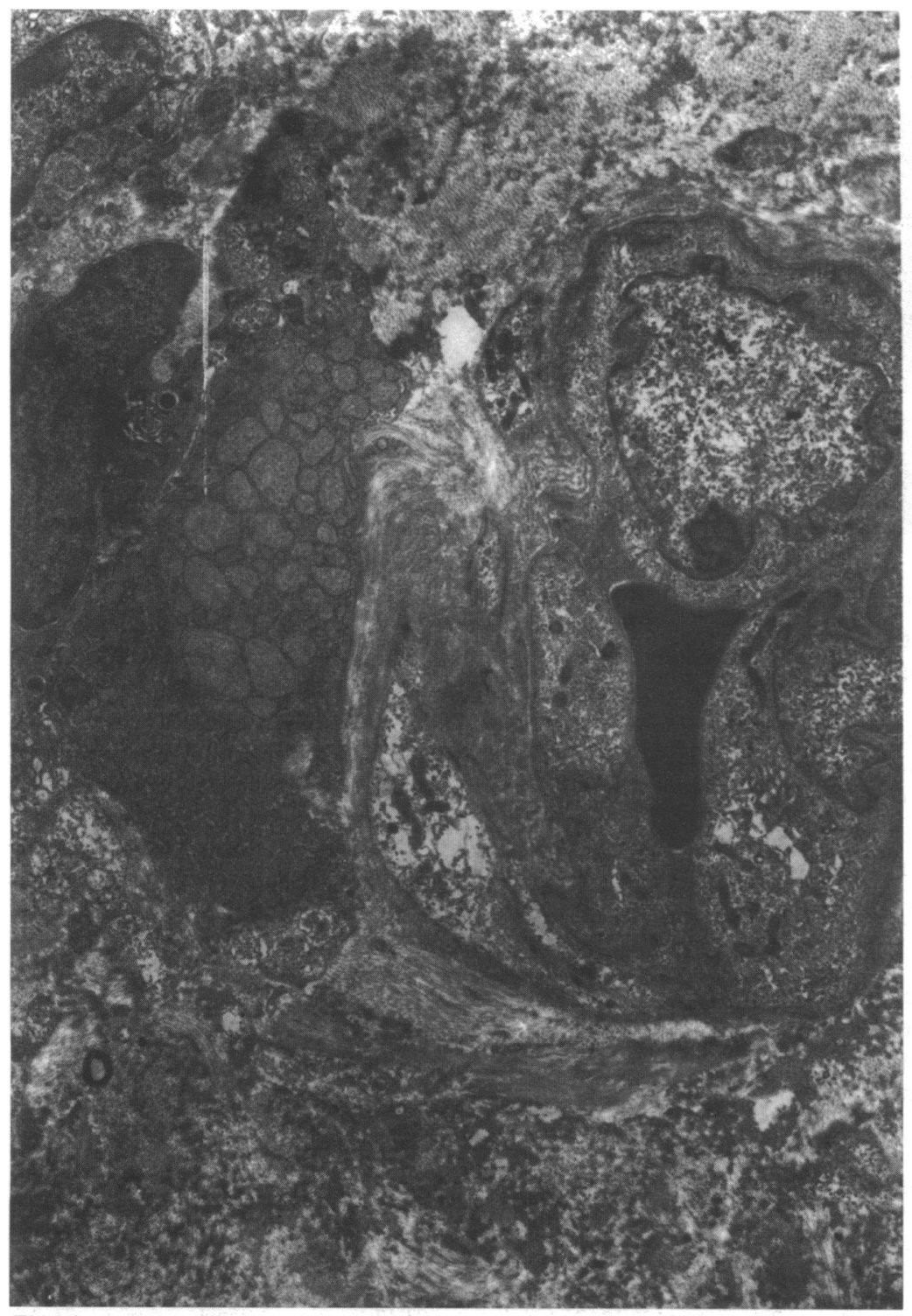

Fig 1 A

Figure 1 Transmission electron micrographs of pterygium sample removed from a corneal site. (A) A capillary is visible embedded in a disorganised mass of collagen. Magnification $\times 5500$. (B) A neural component of the pterygium, with both myelinated, darkly staining myelin sheath and groups of unmyelinated axons (arrowhead), is seen in the connective tissue mass. Magnification $\times 7470$ phase) were seen with increasing numbers of recurrences ( $p>0.05, F$ test, ANOVA).

\section{TRANSMISSION ELECTRON MICROSCOPY}

Transmission electron microscopy (TEM) was used to examine two specimens of pterygium. The general appearance was of a disorganised tissue mass, characterised by large amounts of matrix and collagen interspersed with fibroblasts (Fig 1). A surprising finding was the inclusion of both myelinated and unmyelinated axons. The tissue specimens were removed from a corneal location, so that it is possible that the corneal innervation may have grown into the pterygial mass. Overall, the TEM appearance indicated that the biosynthetic nature of the pterygium was predominant over the proliferative aspects.

\section{PATIENT DATA}

The patients represented by the 48 specimens from Hong Kong were predominantly male (65\%) (Table 3). However, while primary pterygium was nearly equally distributed between the sexes, three quarters of the recurrent lesions were seen in men. Most of the patients had indoor occupations $(60 \%)$; this is not the usual pattern but is probably accounted for by the fact that all 17 women happened to work indoors. Among the male patients, the majority $(19 / 31 ; 61 \%)$ had outdoor occupations.

As would be expected, the patients with primary lesions were younger (mean, 54.8 years) than those with recurrent lesions ( 59.1 years) (Table 3). Similarly, the mean age of the male patients was 55.8 years overall, 53.0 years for primary disease and 56.9 years for recurrent disease. The trend was also seen in the women, who were, however, older in each group: 57.5 years overall, 58.8 years for primary and 60.3 years for recurrent pterygium.

\section{FACTOR ANALYSIS}

Factor analysis revealed three factors (unrotated) that accounted for $71 \%$ of the variance of the data. The first factor had high loadings for two variables - percentage of cells in S (synthetic) phase $(0.936)$, and percentage of cells in $G 2$ and $M$ (mitotic) phases $(0.900)-$ and a high negative loading for percentage of cells in G1 (growth) phase $(-0.942)$. A second factor 


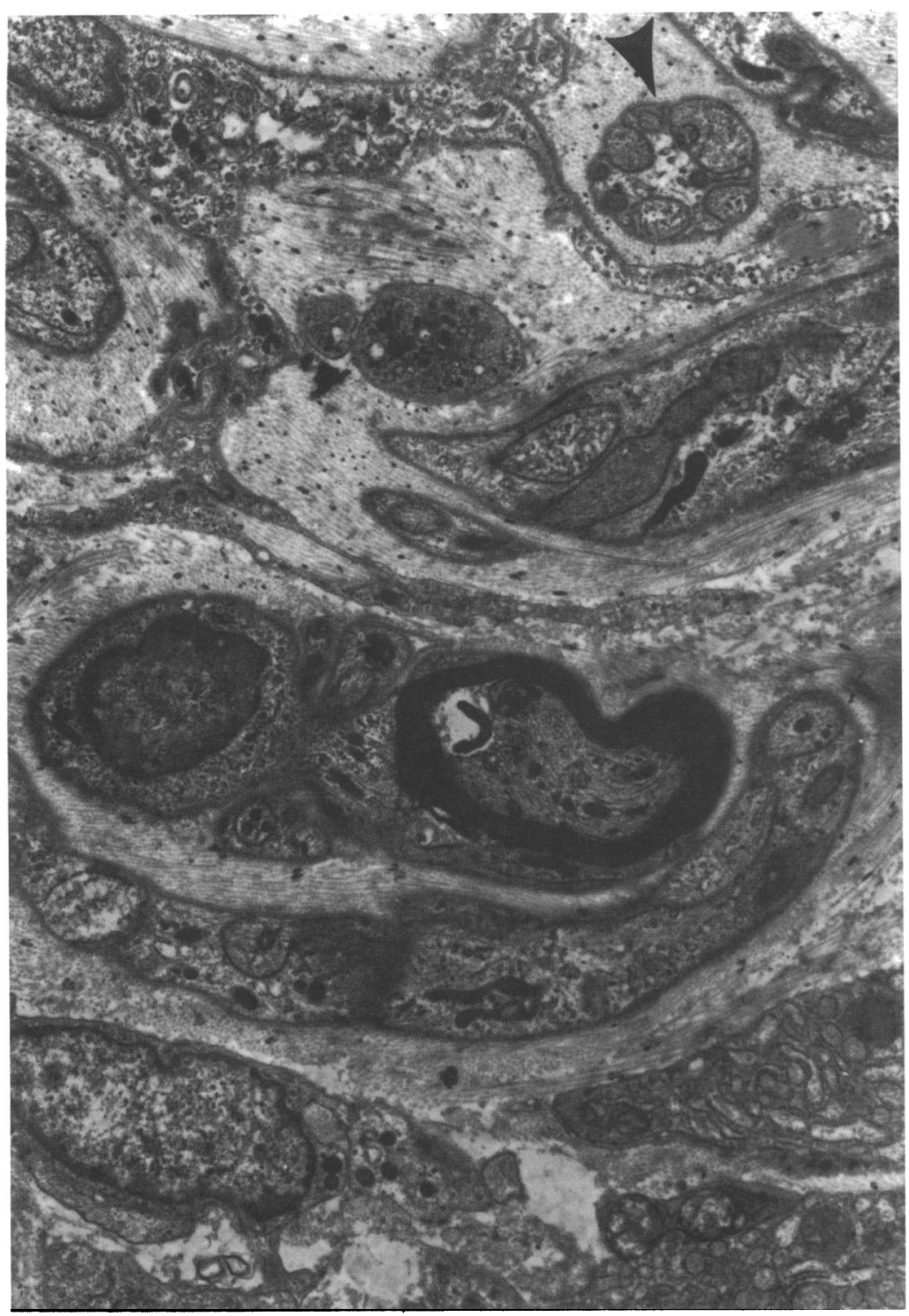

Fig $1 B$ phases, accounted for most of the variance of the data, while recurrence information and occupation were also separately identifiable as contributors to the structure of the data. This shows that, in addition to the expected relations within the phases of the cell cycle (the percentage of $\mathrm{G} 1$ must decrease if the percentages of $S$ and G2M increase in samples of constant numbers of cells), occupation (outdoor), sex (being male), and whether a lesion was primary or secondary all described the scatter of the data.

\section{Discussion}

This study shows that cellular proliferation in pterygium, a conjunctival growth, was not significantly greater than in normal conjunctiva at any of the three geographically distinct locations that were studied (Table 1). Flow cytograms of pterygium specimens did not reveal aneuploidy, suggesting that neoplastic transformations are not part of the pathogenesis of pterygium. Pterygium is a benign condition and we are not aware of any known or reported cases of pterygium with malignant potential. Pterygium is probably caused by an excessive production of extracellular matrix or by the lack of enzymes such as collagenases, leading to tissue accumulation. The presence of extensive extracellular matrix in pterygium has been reported by Austin et $a l^{6}$ and is evident in the electron micrographs of pterygium in our study as well (Fig 1). The ultrastructure of pterygium revealed disorganised swirls of type 1 collagen. An unusual component of one specimen was the presence of myelinated and unmyelinated axons; the origin of these axons is unclear but their source may be the trigeminal system. The possibility of a neurotrophic component to pterygium pathogenesis is also suggested by the ample nerve supply. The importance of innervation for the maintenance of the corneal epithelium has been noted previously. ${ }^{23}$

The implications of our findings are that pharmacological therapies should be directed towards regulation of extracellular matrix production rather than antimitotic approaches such as mitomycin and $\beta$ irradiation. ${ }^{11}{ }^{13-15} \mathrm{It}$ may be that some of the successes attributed to antimitotic approaches are, in fact, the result of toxicity that leads to the loss of cells and a consequent diminished production of extracellular matrix. Safer alternatives without undesirable toxicity may be developed by examining the biosynthetic pathways of extracellular matrix production.

Table 3 Distribution of pterygium by occupation, sex, and age

\begin{tabular}{|c|c|c|c|c|c|}
\hline \multirow{2}{*}{$\begin{array}{l}\text { Type of } \\
\text { pterygium }\end{array}$} & \multirow{2}{*}{$\begin{array}{l}\text { Number of } \\
\text { patients }\end{array}$} & \multirow{2}{*}{$\begin{array}{l}\text { Occupation } \\
\text { indoor/outdoor }\end{array}$} & \multirow{2}{*}{$\frac{\text { Sex }}{M / F}$} & \multicolumn{2}{|c|}{ Age (years) } \\
\hline & & & & Mean & Range \\
\hline $\begin{array}{l}\text { Both primary and recurrent } \\
\text { Primary only } \\
\text { Recurrent only } \\
\text { First recurrence only } \\
\text { Second recurrence only } \\
\text { Third recurrence only }\end{array}$ & $\begin{array}{r}48 \\
30 \\
18 \\
13 \\
3 \\
2\end{array}$ & $\begin{array}{c}29 / 19 \\
20 / 10 \\
9 / 9 \\
7 / 6 \\
0 / 3 \\
2 / 0\end{array}$ & $\begin{array}{l}31 / 17 \\
16 / 14 \\
15 / 5 \\
10 / 3 \\
3 / 0 \\
2 / 0\end{array}$ & $\begin{array}{l}56 \cdot 4 \\
54 \cdot 8 \\
59 \cdot 1 \\
59 \cdot 3 \\
54 \cdot 0 \\
65 \cdot 0\end{array}$ & $\begin{array}{l}23-80 \\
23-79 \\
36-80 \\
36-75 \\
50-62 \\
50-80\end{array}$ \\
\hline
\end{tabular}

Data from Hong Kong only. 
Our study also found that the entire ocular surface proliferates more actively in regions closer to the equator; the cell cycle activity of both pterygium and normal conjunctiva from Singapore $\left(1^{\circ}\right.$ latitude $)$ was significantly greater than the activity of specimens from Hong Kong or Little Rock $\left(22^{\circ}\right.$ and $34^{\circ}$ latitudes, respectively) $(p=0.0001, F$ test, ANOVA). This is consistent with Cameron's survey, which showed an increased incidence of pterygium near the equator. ${ }^{2}$ Hot climates may increase biosynthetic activity of fibroblasts; one factor may be exposure to infrared light, ${ }^{3}$ which is associated with generation of heat, as opposed to exposure to ultraviolet light, which might be expected to be associated with some malignant transformation in pterygium. The data from this study suggest that people living in the tropics have more actively growing ocular surface tissues. Increased pterygium formation in these areas may be a result of the overall increase in mitogenesis. Also, our data argue against pterygial cells as a distinct population of fibroblasts exhibiting deregulation of mitosis. A possible link between proliferation and pterygium formation may be that the latter is the result of an aberrant migration of the products of increased growth.

Patient information revealed that recurrent disease was not more proliferative in nature than primary disease (Table 2). In the data from Hong Kong, twice as many men as women were affected, which is consistent with Townsend's earlier observation. ${ }^{1}$ The total number of patients with indoor occupations was larger than the number with outdoor occupations, probably because virtually all of the women worked indoors; the majority of the affected men had outdoor occupations. Men were also apparently at increased risk of recurrence, although the distribution between the sexes for primary disease was nearly equal. A recent study has uncovered differences between men and women in terms of time to recurrence of pterygium at a particular location; however, the individualising factors were not available. ${ }^{24}$

It was previously noted that peak incidence of pterygium occurs between the ages of 20 and 40 years while the elderly have a higher prevalence. ${ }^{1}$ However, our sample from Hong Kong, a location away from the equator, showed a peak incidence between the ages of 50 and 80 years. It may be that the biosynthetic processes responsible for pterygium take place at a more rapid rate near the equator, leading to early onset of disease, compared with locations such as Hong Kong, which are farther from the equator. Similarly, the interval between primary and recurrent pterygium for the Hong Kong population was 4 years and 6 months, which is much greater than the 6 month interval previously reported. ${ }^{25} 26$
In summary, our results suggest that overexpression of extracellular matrix predominates over cellular proliferation in the pathogenesis of pterygium, and that pharmacological approaches to treatment should, therefore, be directed at reducing the biosynthesis of extracellular matrix rather than inhibition of mitotic activity.

This work was supported in part by US Public Health Service grants EY04074 (Dr Beuerman) and EY02377 (departmenta core facility) from the National Eye Institute, National Institutes of Health, Bethesda, Maryland, an unrestricted departmental grant from Research to Prevent Blindness, Inc, New York, and a Sigma Xi award to Dr Chew.

1 Townsend WM. Pterygium. In: Kaufman HE, Barron BA McDonald MB, Waltman SR, eds. The cornea. New York Churchill Livingstone, 1988: 461-83.

2 Cameron ME. Pterygium throughout the world. Springfield, IL: Charles C Thomas, 1965.

3 Pico G. Pterygium - current concept of etiology and management. In: King JH, McTigue JW, eds. The cornea world congress. Washington, DC: Butterworths, 1965: world cong $280-91$.

4 Hill JC, Maske R. Pathogenesis of pterygium. Eye 1989; 3: 218-26.

5 Barraquer JI. Etiology, pathogenesis and treatment of pterygium. In: Symposium on medical and surgical disease of the cornea. Transactions of the New Orleans Academy of Ophthalmology. St Louis: Mosby, 1980: 167-78.

6 Austin P, Jakobiec FA, Iwamoto T. Elastodysplasia and elastodystrophy as the pathologic bases of ocular pterygia and pinguecula. Ophthalmology 1983; 90: 96-109.

7 Tseng SCG. Staging of conjunctival squamous metaplasia by impression cytology. Ophthalmology 1985; 92: 728-33.

$8 \mathrm{Krag} \mathrm{S}$, Ehlers N. Excimer laser treatment of pterygium. Acta Ophthalmol (Copenh) 1992; 70: 530-3.

9 Zauberman $\mathrm{H}$. Pterygium and its recurrence. Am $f \mathrm{Oph}$ thalmol 1967; 63: 1780-6.

10 Sebban A, Hirst LW. Pterygium recurrence rate at the Princess Alexandra Hospital. Aust NZF Ophthalmol 1991; 19: 203-6.

11 Singh G, Wilson MR, Foster CS. Long-term follow-up study of mitomycin eye drops as adjunctive treatment for pterygia and its comparison with conjunctival autograft transplantation. Cornea 1990; 9: 331-4

12 Hayasaka $S$, Noda $S$, Yamamoto $Y$, Setogawa $T$. Postoperative instillation of mitomycin $c$ in the treatment Postoperative instillation of mitomycin c in the treatment
of recurrent pterygium. Ophthalmic Surg 1989; 20: 580-3.

13 Chapman-Smith JS. Pterygium treatment with triethylene thiophosphoramide. Aust $N Z \mathcal{F}$ Ophthalmol 1992; 20: 129-31.

14 Campbell OR, Amendola BE, Brady LW. Recurrent pterygia: Results of postoperative treatment with $\mathrm{Sr}-90$ applicators. Radiology 1990; 174: 565-6.

15 Dusenberry KE, Alul IH, Khan FM, Levitt SH. Beta irradiation of recurrent pterygia: results and complications. Int $\mathcal{F}$ Radiat Oncol Biol Phys 1992; 24: 315-20.

16 Ling RT. Treatment of pterygium using thermal cautery. Ophthalmic Surg 1989; 20: 511-3.

17 Shaw EL. A modified technique for conjunctival transplant. CLAO F 1992; 18: 112-6.

18 Mackenzie FD, Hirst LW, Battistutta D, Green A. Risk analysis in the development of pterygia. Ophthalmology 1992; 99: 1056-61.

19 Thompson HW, Malter JS, Steinemann TL, Beuerman RW. Flow cytometry measurements of the DNA content of corneal epithelial cells during wound healing. Invest Ophthalmol Vis Sci 1991; 32: 433-6.

20 Milliken GA, Johnson DE. Analysis of messy data. Volume I Designed experiments. New York: Van Nostrand Reinhold, 1984: 197-201.

21 Freund RI, Littell RC. SAS for linear models. A guide to the ANOVA and GLM procedures. Cary, NC: SAS Institute, 1981

22 Harmon HH. Modern factor analysis. Chicago: University of Chicago Press, 1967.

23 Schimmelpfennig B, Beuerman R. A technique for controlled sensory denervation of the rabbit cornea. Graefes Arch Clin Exp Ophthalmol 1982; 218: 287-93.

24 Hirst LW, Sebban A, Chant D. Pterygium recurrence time. Ophthalmology 1994; 101: 755-8.

25 Pico G. Surgery for pterygium. In: Smith BC, Della Rocca RC, Nesi FA, Lisman RD, eds. Ophthalmic plastic and RC, Nesi FA, Lisman RD, eds. Ophthalmic plastic and
reconstructive surgery, Vol 2. St Louis: Mosby, 1987: reconstructive $1416-24$.

26 Chaykul V. Postoperative mitomycin-c eye drop and beta radiation in the treatment of pterygia. $\mathcal{F}$ Med Assoc Thai $1991 ; 74: 373-6$. 